\title{
Colorectal cancer and pancreatic cancer in patients with type 2 diabetes mellitus. Study of the effect of insulin therapy
}

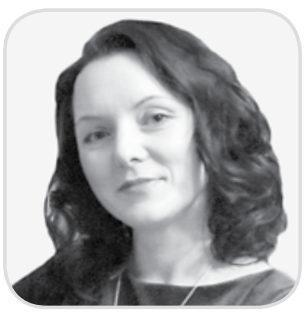

\author{
T. S. Vatseba ', L. K. Sokolova ${ }^{2}$, V. M. Pushkarev ${ }^{2}$
}

${ }^{1}$ Ivano-Frankivsk National Medical University

${ }^{2}$ V. P. Komisarenko Institute of Endocrinology and Metabolism of the NAMS of Ukraine, Kyiv

\section{INTRODUCTION}

The results of scientific studies prove an increased risk of cancer of certain localizations in patients with type 2 diabetes mellitus (T2D), including colorectal and pancreatic cancer [1, 2]. The influence of pathogenetic factors of diabetes: hyperglycemia, hyperinsulinemia, obesity, chronic inflammation, and oxidative stress has been recognized as mechanisms of association between the two diseases [3]. The daily need for drug therapy by diabetic patients has aroused interest for investigating the relationship between antidiabetic drugs (ADD) and oncological diseases (OD). It is clear that the property to lower blood glucose levels, which is inherent for all groups of ADD, has an anticancer effect aimed at hyperglycemia. However, ADD may affect carcinogenesis through their pleiotropic mechanisms, which are associated with the modification of pathogenetic and cancer risk factors.

Numerous scientific studies are devoted to the oncoprotective and anticancer property of metformin, which is realized by reducing insulin resistance and hyperinsulinemia, as well as through proven molecular effects. Metformin activates adenosine monophosphate protein kinase (AMPK), the main regulator of mammalian target of rapamycin (mTOR), a key kinase of the phosphoinositide-3-kinas/protein kinase B/ mTOR (PI3K/Akt/mTOR) signaling pathway involved in the control of cellular metabolism and survival. In addition, the drug can suppress the activity of chronic inflammation by correcting the content of proinflammatory cytokines, reducing the level of free fatty acids (an energy source for the growth of malignant cells), inhibiting the nuclear factor kappa-B cells (NF-KB), that regulates the hypoxia-inducible factor 1-alpha (HIF-1a), which stimulates the synthesis of vascular endothelial growth factor (VEGF) [4].

A lot of studies have shown an increased risk of cancer in patients who undergo sulfonylurea (SU) therapy due to its ability to stimulate insulin release, leading to hyperinsulinemia [5]. However, some studies prove the potential oncoprotective properties of SU derivatives related to their mechanism of action, in particular through their ability to suppress VEGF and neovascularization of malignant neoplasms ( $\mathrm{MN}$ ), reduce tumor necrosis factor-a (TNF-a) levels and the amount of receptors for TNF-a in cancer cells (affecting tumor microenvironment), and due to their antioxidant effects [6].

A great part of scientific studies has been devoted to the study of the risk of MN in patients with diabetes 
receiving insulin therapy. There are conflicting findings regarding the impact of insulin therapy on the development of cancer, in particular, pancreatic and colorectal $[7,8]$.

Objective - to investigate the influence of insulin therapy on the incidence of cases of pancreatic and colorectal cancer.

\section{MATERIAL AND METHODS}

The study was conducted in accordance with the guidelines of the 1975 Declaration of Helsinki and its revised version of 1983. The study included the analysis of statistical data about the incidence of cases of T2D among the population of Ivano-Frankivsk region (Ukraine). The summary data of the state statistical form \# 12 «Report on diseases that were registrated in patients living in the area of service of a health care facility» for the population of Ivano-Frankivsk region were used, according to which there were 42,532 patients with T2D in the region for the period 2012$2016,4,376$ of them were on insulin therapy, 38,156 - have not received any insulin therapy. Besides, the study included analysis of medical records of patients with pancreatic and colorectal cancer, which was first diagnosed in people with T2D during 2012-2016. The bases for this part of the study were: Precarpathian Oncology Center, Regional Clinical Hospital in IvanoFrankivsk and other specialized medical institutions of the Ivano-Frankivsk region.

The obtained results were processed using statistical programs «Microsoft Excel» and «Statistika-12». Two compared groups represented patients with pancreatic cancer and colorectal cancer, respectively. Age, body mass index (BMI), glycosylated hemoglobin ( $\mathrm{HbA1c})$ levels, duration of T2D were used to represent patients' clinical characteristics. The arithmetic mean (M), standard deviation (SD), number of the variant (n) were used for the processing of these data. Differences between values were determined using the Student's t-test. The differences were considered significant at $p<0.05$.

For the analysis of $\mathrm{BMI}$ the classification of $\mathrm{WHO}$ was used: $18.5-24.9 \mathrm{~kg} / \mathrm{m}^{2}-$ normal weight, $25.0-$ $29.9 \mathrm{~kg} / \mathrm{m}^{2}$ - overweight, $30.0-34.9 \mathrm{~kg} / \mathrm{m}^{2}$ - obesity class I, $35.0-39.9 \mathrm{~kg} / \mathrm{m}^{2}$ - obesity class II, over $40 \mathrm{~kg} / \mathrm{m}^{2}$ - obesity class III.

Treatment of patients in the comparison groups included various ADD regimens that included metformin from the biguanide group; glimepiride, gliclazide and glibenclamide from the group of SU derivatives; sitagliptin from the group of inhibitors of dipeptidyl peptidase 4 (DPP-4 inhibitors or gliptins) and insulin therapy with human insulin and insulin analogues.

Using the method $X^{2}$-Pearson's square with the correction for the Yates continuity the connection between the treatment with different groups of ADD and the incidence of these OD was revealed. The connection was considered significant at $p<0.05$. The odds ratio $(\mathrm{OR}), 95 \%$ confidence interval $(\mathrm{Cl})$, the positive and negative predictive values were calculated to determine the probability of occurrence of pancreatic and colorectal cancer in insulindependent patients. Statistical relation was significant at $p<0.05$.

\section{RESULTS AND DISCUSSION}

According to the National Cancer Registry of Ukraine, 2,168 cases of colorectal cancer (including colon and rectal cancer) and 650 cases of pancreatic cancer were diagnosed in Ivano-Frankivsk region during 20122016. Prior to the detection of OD among these patients, 72 patients with colorectal cancer ( 32 women, 40 men) and 52 patients ( 24 women, 28 men) with pancreatic cancer had T2D [9].

The average age of patients with diabetes at the time of cancer detection was more than 60 years old. Patients with colorectal cancer had a significantly higher BMI compared to patients with pancreatic cancer $(p<0.05)$. The level of HbA1c was significantly higher in patients (females) with colorectal cancer than in patients with pancreatic cancer $(p<0.05)$ (Table 1).

The age-related characteristics of patients with MN of the pancreas and colorectal localization (Table 1) confirm the known statistics on the prevalence of tumors in older people. OD are recognized as diseases that are associated with the processes of aging, a decrease of the immune system's control and response to the influence of epigenetic factors of oncogenesis (including dysmetabolic factors) [10].

Many studies prove the impact of obesity on the development of cancer of both localizations [11, 12]. Obesity is known to promote carcinogenesis through macrophage infiltration of adipose tissue, chronic inflammatory state and cytokine imbalance. In the etiology of colorectal cancer, the interference of the gut microbiota, which regulates the expression of genes involved in the formation of the immune response of the organism, including oncogenesis, is of great importance [12]. 
Clinical characteristics of patients with pancreatic and colorectal cancer $(M \pm S D)$

\begin{tabular}{|l|l|l|l|l|}
\hline Variables & $\begin{array}{l}\text { Colorectal cancer } \\
\text { (n= 72) }\end{array}$ & $\begin{array}{l}\text { Pancreatic cancer } \\
\text { (n= 52) }\end{array}$ & t & p \\
\hline Age, years & $65.94 \pm 7.35$ & $67.13 \pm 7.82$ & 0.88 & 0.383 \\
males females & $64.50 \pm 6.45$ & $67.21 \pm 8.36$ & 1.51 & 0.136 \\
& $67.72 \pm 8.09$ & $67.04 \pm 7.32$ & 0.32 & 0.748 \\
\hline BMl, kg/m² & $30.72 \pm 4.02$ & $27.08 \pm 3.54^{*}$ & 5.22 & $<0.001$ \\
males females & $30.70 \pm 4.33$ & $27.18 \pm 3.82^{*}$ & 3.50 & 0.008 \\
& $30.74 \pm 3.66$ & $26.96 \pm 3.22^{*}$ & 3.96 & $<0.001$ \\
\hline HbA1c, \% males & $8,47 \pm 1.40$ & $7.87 \pm 0.71$ & 2.82 & 0.006 \\
females & $8,44 \pm 1.52$ & $7.92 \pm 0.68$ & 1.68 & 0.097 \\
& $8,51 \pm 1.25$ & $7.82 \pm 0.76^{*}$ & 2.39 & 0.020 \\
\hline
\end{tabular}

Note: Student's t-test; $\mathrm{t}-\mathrm{t}$ value for comparing between the two groups; $\mathrm{p}-\mathrm{p}$ value for the evaluation of significance of the $\mathrm{t}$; * - the difference is statistically significant at $p<0.05$.

Significantly higher prevalence of obesity in patients with colorectal cancer is revealed using BMI analysis (Figure 1, 2).

The small number of obese patients in the group with pancreatic cancer (Figure 1) may be explained by the heterogeneity of diabetes types in this group. It is possible to assume that group included not only patients with $\mathrm{T} 2 \mathrm{D}$, but also with pancreatogenic diabetes type 3 ( $T 3 C D M)$, caused by damage to the glandular parenchyma by the tumor processes, and which was classified as T2D.

Clinical observations and scientific studies show that $50-80 \%$ of cases of cancer of the pancreas are accompanied by diabetes, on the other hand, patients with newly diagnosed diabetes have cancer diagnosed with a frequency from $0.85 \%$ to $7.0 \%$ [13]. It is suggested to determine the presence of a complex of such features as exocrine insufficiency of pancreas

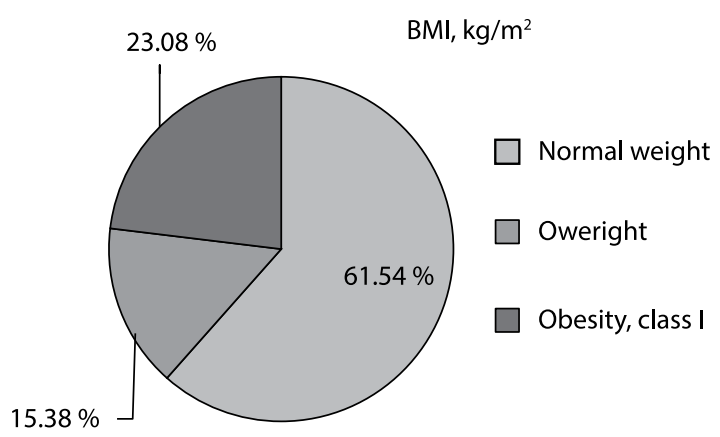

Fig. 1. BMI in patients with pancreatic cancer: normal body weight: BMI $18.5-24.9 \mathrm{~kg} / \mathrm{m}^{2}$; overweight: BMI $25.0-29.9 \mathrm{~kg} / \mathrm{m}^{2}$; obesity class I: BMI $30.0-34.9 \mathrm{~kg} / \mathrm{m}^{2}$ (confirmed by determining the content of fecal elastase-1 or pancreatic polypeptide), visualization of abnormalities of the structure of pancreas (through endoscopic ultrasound, magnetic resonance tomography (MRT) or computed tomography (CT) of gland), negative markers of type 1 diabetes, absence of insulin resistance, impaired secretion of incretin (glucagon-like peptide-1 (GLP-1)) and low serum concentrations of fat-soluble vitamins $(A, D, E$, and $K)$ as diagnostic criteria of T3CDM [14]. These main indicators of T3CDM were not determined in the examined patients. However, indirect evidence of possible pancreatic cancer-related diabetes are lack of obesity and, probably, insulin resistance at the examined patients.

The previously obtained results of another fragment of this scientific study revealed no difference in insulin content in patients with pancreatic cancer (also without obesity), detected on the background of T2D compared with the control group. However, a significantly lower insulin content in patients with pancreatic cancer compared with patients with T2D without cancer has been proven [15].

The prevalence of obesity in patients with colorectal cancer (Figure 2) confirms its prooncogenic effect through the development of insulin resistance, hyperinsulinemia, chronic inflammation, cytokine imbalance and alteration of the gut microbiota. An excessive amount of insulin through the activation of its receptors (IR), as well as receptors of insulin-like growth factor (IGF-1R), stimulates the $\mathrm{PI} 3 \mathrm{~K} / \mathrm{Akt} / \mathrm{mTOR}$ signaling pathway and activates a large number of protein kinases and transcription 
factors involved in the regulation of cellular survival and apoptosis.

Chronic inflammation and proinflammatory cytokines form a microenvironment favorable for malignant cells, causing the activation of NF-KB, responsible for the expression of genes that control the cell cycle and the immune response. Hypoadiponectinemia in obesity leads to the suppression of AMPK and the transcription factor p53 - tumor suppressor. Lower adiponectin levels have been associated with the P12A mutation in peroxisome proliferator-activated receptor-gamma (PPAR $\gamma)$, which promotes angiogenesis and survival of malignant cells [16].

A comparative analysis of the duration of diabetes in patients before the revealing of cancer was performed. The results showed that pancreatic cancer and colorectal cancer were diagnosed with different duration of diabetes (Table 2).

According to the data obtained, colorectal cancer was diagnosed in patients with a significantly longer duration of DM than in patients with pancreatic cancer $(p<0.001)$ (Table 2).

It was found that before the detection of pancreatic cancer, 17 patients ( $32.69 \%$ ) had a duration of diabetes up to 1 year; 24 patients ( $46.15 \%)$ had diabetes for $1-5$ years; 11 patients $(21.15 \%)-$ more than 5 years. In the case of colorectal cancer, the duration of diabetes up to 1 year was 2 people $(2.78 \%) ; 1-5$ years 12 patients $(16.67 \%)$; more than 5 years -58 patients (80.56\%).

Huxley R. et al. proved that patients with a duration of T2D up to 4 years to have a $50 \%$ higher risk of pancreatic cancer compared to those, who suffer for more than 4 years [1]. It has been proved that ductal adenocarcinoma of the pancreas causes peripheral insulin resistance and cancer-associated diabetes [17]. Further discussions and research are still being carried

Table 2

Duration of type 2 diabetes in patients before cancer detection $(M \pm S D)$

\begin{tabular}{|l|l|l|l|l|}
\hline $\begin{array}{l}\text { Localisation of } \\
\text { cancer }\end{array}$ & $\begin{array}{l}\text { Colorectal } \\
\text { cancer } \\
(\mathbf{n}=\mathbf{7 2})\end{array}$ & $\begin{array}{l}\text { Pancreatic } \\
\text { cancer } \\
\mathbf{( n = 5 2 )}\end{array}$ & $\mathbf{P}$ & $\mathbf{P}$ \\
\hline $\begin{array}{l}\text { Duration DM, } \\
\text { years }\end{array}$ & $9.83 \pm 6.57^{*}$ & $4.12 \pm 3.97$ & 5.58 & $<0.001$ \\
\hline
\end{tabular}

Note: Student's $\mathrm{t}$ - test; $\mathrm{t}$ - $\mathrm{t}$ value for comparing between the two groups; $p-p$ value for the evaluation of significance of the $t$; * - the difference is statistically significant at $\mathrm{p}<0.05$.

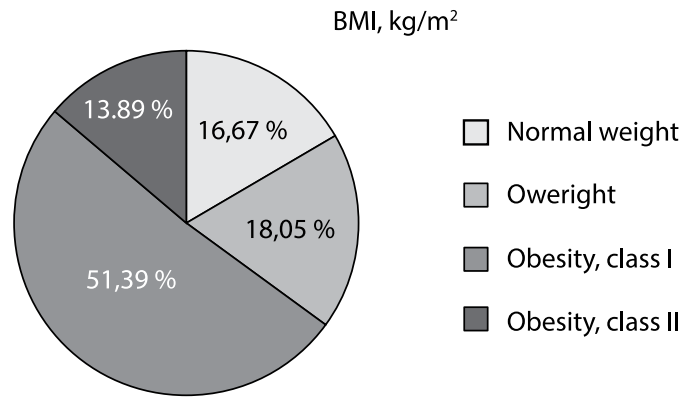

Fig. 2. $B M I$ in patients with colorectal cancer: normal body weight: BMI 18.5-24.9 kg/m²; overweight: BMI $25.0-29.9 \mathrm{~kg} / \mathrm{m}^{2}$; obesity class I: $B M I 30.0-34.9 \mathrm{~kg} / \mathrm{m}^{2}$; obesity class II: $B M I 35.0-39.9 \mathrm{~kg} / \mathrm{m}^{2}$

out on the anteriority of the occurrence of diabetes or cancer of the pancreas.

The analysis of antidiabetic therapy was performed in patients with T2D before the diagnosing of colorectal and pancreatic cancer (Table 3).

According to the data in Table 3, the treatment of patients with T2D in the compared groups before the detection of cancer was different. It should be noted that 14 patients with pancreatic cancer $(26.92 \%)$ were treated with SU (monotherapy), while in the group of patients with colorectal cancer only 9 patients received this therapy $(12.50 \%) .12$ individuals with pancreatic cancer $(23.08 \%)$ and 6 with colorectal cancer $(8.33 \%)$ were on insulin monotherapy. The frequency of taking metformin in the compared groups is also quite different. Thus, 16 patients (30.77\%) received metformin in the group with pancreatic cancer, and 53 patients (73.61\%) with colorectal cancer (as monotherapy or in combination with other medication). Insulin analogs were received by 3 patients from each of the compared groups.

The prevalence of monotherapy with SU derivates and insulin in patients with pancreatic cancer (with a predominant duration of diabetes up to 5 years) before the detection of MN may be indicative of a state of insulin shortage or its absolute deficiency, which is not entirely typical for the treatment of T2D with such duration. Regarding the spectrum of therapy for patients with colorectal cancer, the widespread use of metformin may be a valid influence on the state of insulin resistance, which is evidenced by overweight in the majority of patients in this group (Figure 2).

According to Table 3, the choosing of antidiabetic therapy used to treat patients in the compared groups 
The differences in antidiabetic drugs between patients with pancreatic and colorectal cancers before the diagnosis of malignancy

\begin{tabular}{|l|l|l|l|l|l|l|}
\hline \multirow{2}{*}{} & \multicolumn{2}{|l|}{$\begin{array}{l}\text { The number of patients } \\
\text { with pancreatic cancer } \\
\text { (n= 52) }\end{array}$} & $\begin{array}{l}\text { The number of patients } \\
\text { with colorectal cancer } \\
\text { (n= 72) }\end{array}$ & $X^{\mathbf{2}}$ & p \\
\cline { 1 - 5 } & $\begin{array}{l}\text { with } \\
\text { specified } \\
\text { type of } \\
\text { therapy }\end{array}$ & $\begin{array}{l}\text { without } \\
\text { specified } \\
\text { type of } \\
\text { therapy }\end{array}$ & $\begin{array}{l}\text { with } \\
\text { specified } \\
\text { type of } \\
\text { therapy }\end{array}$ & $\begin{array}{l}\text { without } \\
\text { specified } \\
\text { type of } \\
\text { therapy }\end{array}$ & & \\
\hline Diet therapy & 9 & 43 & 5 & 67 & 2.29 & 0.131 \\
\hline Metformin (monotherapy) & 2 & 50 & 9 & 63 & 1.83 & 0.176 \\
\hline SU (monotherapy) & 14 & 38 & 9 & 63 & 3.26 & 0.071 \\
\hline Insulin (monotherapy) & 12 & 40 & 5 & 67 & $5.35^{*}$ & 0.021 \\
\hline Metformin + SU & 10 & 42 & 29 & 43 & $5.27^{*}$ & 0.022 \\
\hline Metformin + Gliptins & 3 & 49 & 1 & 71 & 0.72 & 0.371 \\
\hline Metformin + Insulin & 1 & 51 & 13 & 59 & $6.32^{*}$ & 0.012 \\
\hline Insulin + SU & 1 & 51 & 0 & 72 & 0.03 & 0.870 \\
\hline Metformin + Insulin + Gliptins & 0 & 52 & 1 & 71 & 0.03 & 0.870 \\
\hline
\end{tabular}

Note: $p-$ value for the evaluation of the significance of the relation between two groups; ${ }^{*}$ - the connection is significant $(p<0.05)$; results are presented as $x^{2}$-test for assessment of significance of the relationship between the categorical variables.

are significantly different. This difference may be partly due to the anthropometric parameters of patients (Table 1).

For the most part, it is more common to choose firstline drugs with non-pancreatic effects and with insulin resistance correcting property. Over time, the need for $\mathrm{SU}$ and insulin increases.

The duration of diabetes less than 5 years was discovered in 8 of 12 patients $(66.67 \%)$, who had pancreatic cancer and were treated with insulin, in case of colorectal cancer, only 1 of 5 patients (20.00\%) had this duration of the disease and received insulin as well.
Based on statistical data about incidence of T2D among the population of Ivano-Frankivsk region and taking into account the incidence of pancreatic and colorectal cancer among them, the relation between insulin therapy (before the detection of $\mathrm{MN}$ ) and the occurrence of OD these localizations was determined (Table 4).

Statistical analysis revealed an increased probability of pancreatic [OR $=3.21 ; 95 \% \mathrm{Cl}(1.74-5.93) ; \mathrm{p}<0.001]$ and colorectal cancer $[\mathrm{OR}=3.13 ; 95 \% \mathrm{Cl}(1.85-5.28)$; $\mathrm{p}<0.001]$ associated with insulin therapy in patients with T2D (Table 4).

Relation between insulin therapy and the occurrence of pancreatic and colorectal cancer in patients with T2D

\begin{tabular}{|c|c|c|c|c|c|c|c|}
\hline \multirow[t]{2}{*}{ Cancer localization } & \multicolumn{2}{|c|}{$\begin{array}{l}\text { The number of patients } \\
\text { with T2D without insulin }\end{array}$} & \multicolumn{2}{|c|}{$\begin{array}{l}\text { The number of patients with } \\
\text { T2D with insulin therapy }\end{array}$} & \multirow[t]{2}{*}{ OR } & \multirow[t]{2}{*}{$95 \% \mathrm{Cl}$} & \multirow[t]{2}{*}{$p$} \\
\hline & total & with OD & total & with OD & & & \\
\hline $\begin{array}{l}\text { Pancreatic cancer } \\
(\mathrm{n}=52)\end{array}$ & 38156 & 38 & 4376 & 14 & 3.21 & $1.74-5.93$ & $<0.001$ \\
\hline $\begin{array}{l}\text { Colorectal cancer } \\
(n=72)\end{array}$ & 38156 & 53 & 4376 & 19 & 3.13 & $1.85-5.28$ & $<0.001$ \\
\hline
\end{tabular}

Note: results are presented as OR for determination of the relation between insulin therapy and the occurrence of pancreatic and colorectal cancer in patients with T2D. 
In this case, it is impossible to fully confirm the effect of insulin therapy on the development of pancreatic cancer, as the clinical characteristics of patients (BMI, duration of diabetes, early insulin prescription) may be a reflection of the misclassification of T3CDM as T2D. The impact of insulin therapy on cancer risk through molecular mechanisms has been proved in many studies. Insulin is known to activate the processes of oncogenesis through the stimulation of PI3K/Akt/ mTOR, the activation of lipogenesis, the increase in $\mathrm{BMI}$ that causes insulin resistance, hyperinsulinemia and hyperglycemia. In addition, when treating patients with T2D, it is almost impossible to achieve a physiological concentration of insulin by exogenously injecting it, since low insulin sensitivity causes the overdose of insulin, and therefore insulin therapy promotes secondary insulin resistance, forming a closed circle, which is favorable for neoplasia [18]. Therefore the use of physiologically safe doses of insulin and the correction of insulin resistance are the ways to prevent cancer in patients with T2D.

Published in 2012, results of a study by Colmers I.N. et al. have confirmed an increased risk of pancreatic cancer in patients with recent prescription of human insulin and insulin analogs, as well as a reduced risk of colorectal cancer. Regarding the cases of pancreatic cancer, the authors also suggested the existence of T3cDM patients, who needed early insulin therapy [7]. In other studies, the effect of insulin therapy on the risk of pancreatic as well as colorectal cancer has been proved $[19,20]$.

Data on the effects of insulin analogs also differ. In an international multicenter study, conducted by But A. et al., the increased oncological risk, caused by insulin analogs compared to human insulin, was not found. The CARING study found an increased risk of colorectal cancer (no gender differences) in patients during the first year of using insulin analogs. However, the results were partly explained by the fact that, traditionally, insulin analogs were used after a period of therapy with human insulin, so the decompensation of diabetes (as indicated by the appointment of analogs) may be a sign of cancer [21]. Therefore, the study of these issues is still going on.

\section{CONCLUSIONS}

1 The findings suggest the association of insulin therapy and the occurrence of pancreatic cancer and colorectal cancer in patients with type 2 diabetes mellitus.

2. Cases of pancreatic cancer require further study and exclusion of possibility of patients having type 3 diabetes (T3CDM) already at the initial diagnosis.

Acknowledgments. The author is grateful to the staff of the departments of statistical information processing and archive of the regional hospital of Ivano-Frankivsk and the Precarpathian Oncology Center, as well as endocrinologists of medical institutions of Ivano-Frankivsk region for their assistance in collecting the data required for this research.

Ethics policy. The study is a fragment of the research project «Epidemiology of oncological diseases in patients with diabetes mellitus and the effect of antihyperglycemic drugs on oncogenesis markers» (registration number 0117U005263), included into the complex research work of Ivano-Frankivsk National Medical University «Pathogenetic mechanisms of development of changes in organs of the respiratory, endocrine, nervous systems in the modeled pathological conditions and their correction» (registration number 0117U001758), without special funding.

The study protocol was reviewed and approved by the Ethics Committee of Ivano-Frankivsk National Medical University (protocol No. 97/17 of October 19, 2017).

Conflicts of interest. The author declares that there is no conflict of interest.

\section{REFERENCES}

1. Huxley R, Ansary-Moghaddam A, Berrington de González A et al. Type-Il diabetes and pancreatic cancer: a meta-analysis of 36 studies. Br J Cancer. 2005;92(11):2076-83. doi: 10.1038/sj.bjc.6602619.

2. Peeters PJ, Bazelier MT, Leufkens HG et al. The risk of colorectal cancer in patients with type 2 diabetes: associations with treatment stage and obesity. Diabetes Care. 2015;38(3):495-502. doi: 10.2337/dc14-1175.

3. Pushkarev VM, Sokolova LK, Pushkarev VV et al. Biokhimicheskiye mekhanizmy, svyazyvayushchiye diabet i rak. Deystviye metformina [Biochemical mechanisms connecting diabetes and cancer. Effects of methormine]. Endokrynologia 2018; 23(2):167-79 (Ukrainian).

4. Saini N, Yang X. Metformin as an anti-cancer agent: actions and mechanisms targeting cancer stem cells. Acta Biochim Biophys Sin (Shanghai). 2018;50(2):13343. doi: 10.1093/abbs/gmx106.

5. Dąbrowski M, Szymańska-Garbacz E, Miszczyszyn Z et al. Antidiabetic medications use and cancer risk in type 
2 diabetes. Clinical Diabetology 2017; 6(1):17-25. doi: 10.5603/DK.2017.0004.

6. Hendriks AM, Schrijnders $D$, Kleefstra $\mathrm{N}$ et al. Sulfonylurea derivatives and cancer, friend or foe? Eur J Pharmacol. 2019;861:172598. doi: 10.1016/j. ejphar.2019.172598.

7. Colmers IN, Bowker SL, Tjosvold LA et al. Insulin use and cancer risk in patients with type 2 diabetes: a systematic review and meta-analysis of observational studies. Diabetes Metab. 2012;38(6):485-506. doi: 10.1016/j. diabet.2012.08.011.

8. Janghorbani M, Dehghani M, Salehi-Marzijarani M. Systematic review and meta-analysis of insulin therapy and risk of cancer. Horm Cancer. 2012;3(4):137-46. doi: 10.1007/s12672-012-0112-z.

9. Bulletin of National Cancer Registry of Ukraine № 14-18, 2012-2016. Available from: http://www.ncru.inf.ua/.

10. Campisi J. Aging, cellular senescence, and cancer. Annu Rev Physiol. 2013;75:685-705. doi: 10.1146/annurevphysiol-030212-183653.

11. Martinez-Useros J, Garcia-Foncillas J. Obesity and colorectal cancer: molecular features of adipose tissue. J Transl Med. 2016;14:21. doi: 10.1186/s12967-0160772-5.

12. Pothuraju R, Rachagani $S$, Junker WM et al. Pancreatic cancer associated with obesity and diabetes: an alternative approach for its targeting. J Exp Clin Cancer Res. 2018;37(1):319. doi: 10.1186/s13046-018-0963-4.

13. Chari ST, Leibson CL, Rabe KG et al. Probability of pancreatic cancer following diabetes: a populationbased study. Gastroenterology. 2005;129(2):504-11. doi: 10.1016/j.gastro.2005.05.007.

14. Ewald N, Bretzel RG. Diabetes mellitus secondary to pancreatic diseases (Type 3c)-are we neglecting an important disease? Eur J Intern Med. 2013;24(3):203-6. doi: 10.1016/j.ejim.2012.12.017.

15. Vatseba T.S. Type 2 diabetes mellitus: a marker or a risk factor for pancreatic cancer? Clinical endocrinology and endocrine surgery. 2019;3(67):45-52. doi:10.30978/ CEES-2019-3-45.

16. Monks M, Irakleidis F, Tan PH. Complex interaction of adiponectin-mediated pathways on cancer treatment: a novel therapeutic target. J Cancer Metastasis Treat 2019;5:24. doi:10.20517/2394-4722.2018.79.

17. Basso $D$, Valerio $A$, Seraglia $R$ et al. Putative pancreatic cancer-associated diabetogenic factor: $2030 \mathrm{MW}$ peptide. Pancreas. 2002;24(1):8-14. doi: 10.1097/00006676-200201000-00002.

18. Tseng $\mathrm{CH}$. Prolonged use of human insulin increases breast cancer risk in Taiwanese women with type 2 diabetes. BMC Cancer. 2015;15:846. doi: 10.1186/ s12885-015-1876-7.

19. Lu Y, García Rodríguez LA, Malgerud L et al. Newonset type 2 diabetes, elevated $\mathrm{HbA} 1 \mathrm{c}$, anti-diabetic medications, and risk of pancreatic cancer. $\mathrm{Br} \mathrm{J}$ Cancer. 2015;113(11):1607-14. doi: 10.1038/ bjc.2015.353.

\section{SUMMARY}

\section{Colorectal cancer and pancreatic cancer in patients with type 2 diabetes mellitus. Study of the effect of insulin therapy}

\section{T. S. Vatseba ', L. K. Sokolova ${ }^{2}$, V. M. Pushkarev ${ }^{2}$}

'Ivano-Frankivsk National Medical University

${ }^{2}$ V. P. Komisarenko Institute of Endocrinology and Metabolism of the NAMS of Ukraine, Kyiv

Patients with type 2 diabetes have increased cancer risk. The study of the role of antidiabetic drugs in the processes of oncogenesis, in particular insulin therapy, continues.

Objective - to investigate the influence of insulin therapy on the incidence of pancreatic and colorectal cancer.

Materials and methods. The study included an analysis of medical records of patients with type 2 diabetes, who were first diagnosed with colorectal or pancreatic cancer during 2012-2016. Relation between incidence of these cancers and obesity, duration of diabetes, types of antidiabetic therapy, in particular with insulin therapy, has been studied.

Results and discussion. During the study period, 52 cases of the first diagnosed pancreatic and 72 cases of colorectal cancer in patients with type 2 diabetes were detected. Obesity was detected in $65.28 \%$ of patients with colorectal and in $23.08 \%$ of patients with pancreatic cancer. Pancreatic cancer was more commonly diagnosed in patients with duration of diabetes up to 5 years $(78.85 \%)$, colorectal cancer - over 5 years $(80.56$ $\%)$. Significant influence of insulin therapy on the occurrence of pancreatic [OR $=3.21 ; 95 \% \mathrm{Cl}(1.74-5.93)$; $\mathrm{p}<0.001]$ and colorectal cancer $[\mathrm{OR}=3.13 ; 95 \% \mathrm{Cl}$ (1.85-5.28); $\mathrm{p}<0.001]$ was detected.

Conclusions. The findings suggest the association between insulin therapy and the occurrence of pancreatic and colorectal cancer in patients with type 2 diabetes mellitus. However, cases of pancreatic cancer require further study and exclusion of possibility of patients having type $3 \mathrm{c}$ diabetes already at the initial diagnosis. 
Key words: type 2 diabetes, insulin therapy, colorectal cancer, pancreatic cancer.

\section{PEЗЮME}

Колоректальний рак і рак підшлункової залози у хворих на цукровий діабет 2 типу. Дослідження впливу інсулінотерапії

\section{T. С. Вачеба' ', Л. К. Соколова' ${ }^{2}$ В. М. Пушкарьов ${ }^{2}$}

'/вано-Франківський начіональний медичний університет

${ }^{2}$ ДУ «Інститут ендокринології та обміну речовин імені В. П. Комісаренка НАМН України», Київ

У хворих на цукровий діабет 2 типу доведений підвищений ризик онкологічних захворювань. Триває вивчення ролі цукрознижувальних препаратів у процесах онкогенезу, зокрема інсулінотерапії.

Мета роботи - дослідити вплив інсулінотерапії на розвиток раку підшлункової залози та колоректальний рак.

Матеріали та методи. Проведено аналіз медичних карт пацієнтів із злоякісними пухлинами колоректальної локалізації та підшлункової залози, які були вперше діагностовані у хворих на цукровий діабет 2 типу у 2012-2016 pp.

Результати та обговорення. За досліджуваний період у хворих на цукровий діабет 2 типу виявлено 52 випадки вперше діагностованих злоякісних пухлин підшлункової залози та 72 - колоректального раку, переважно в осіб віком понад 60 років. Ожиріння мало місце у 65,28 \% хворих з колоректальним раком і у 23,08 \% - з раком підшлункової залози. Злоякісні пухлини підшлункової залози найчастіше діагностували за тривалості діабету до 5 років (78,85\%), а колоректальний рак - за тривалості 5 років (80,56 \%). Серед хворих із злоякісними новоутвореннями підшлункової залози монотерапію інсуліном застосовували 12 (23,08 \%) осіб, з них у $8(66,67 \%)$ тривалість діабету становила менше 5 років. Серед хворих із колоректальним раком 5 осіб отримували монотерапію інсуліном (8,33 \%), лише 1 (20,00 \%) пацієнт мав стаж діабету менше 5 років. Виявлено ймовірний вплив інсулінотерапії на виникнення раку підшлункової залози (відношення шансів - 3,21; 95 \% довірчий інтервал - 1,745,93; $\mathrm{p}<0,001$ ) і колоректального раку (відношення шансів - 3,13; $95 \%$ довірчий інтервал - 1,85-5,28; $\mathrm{p}<0,001)$.

Висновки. Отримані дані свідчать про ймовірну асоціацію між інсулінотерапією та виникненням раку підшлункової залози та колоректальної локалізації у пацієнтів із цукровим діабетом 2 типу. Хворі з раком підшлункової залози потребують додаткового обстеження та заперечення можливого T3cDM у разі вперше виявленого цукрового діабету.

Ключові слова: цукровий діабет 2 типу, інсулінотерапія, рак підшлункової залози та колоректальний рак.

\section{PEЗЮME}

Колоректальный рак и рак поджелудочной железы у больных с сахарным диабетом 2 типа. Исследование влияния инсулинотерапии

\section{Т. С. Вачеба' ', Л. К. Соколова², В. М. Пушкарев ${ }^{2}$}

\author{
' Ивано-Франковский национальный медичинский \\ университет \\ ${ }^{2} Г У$ «Институт эндокринологии и обмена веществ \\ имени. В. П. Комиссаренко НАМН Украины», Киев
}

У больных с сахарным диабетом 2 типа доказан повышенный риск онкологических заболеваний. Продолжается изучение роли противодиабетических препаратов в процессах онкогенеза, в частности инсулинотерапии.

Цель работы - исследовать влияние инсулинотерапии на развитие рака поджелудочной железы и колоректального рака.

Материалы и методы. Проведен анализ медицинских карт пациентов со злокачественными опухолями колоректальной локализации и поджелудочной железы, которые были впервые диагностированы у больных с сахарным диабетом 2 типа в 2012-2016 гг.

Результаты и обсуждения. За исследуемый период у больных с сахарным диабетом 2 типа выявлено 52 случаявпервыедиагностированныхзлокачественных опухолей поджелудочной железы и 72 - колоректального рака, преимущественно у лиц старше 60 лет. Ожирение имело место у 65,28\% больных с колоректальным раком и у $23,08 \%$ - с раком поджелудочной железы. Злокачественные опухоли поджелудочной железы чаще диагностировали при длительности сахарного диабета до 5 лет $(78,85 \%)$, а колоректальный рак - при длительности диабета более 5 лет (80,56 \%). Среди больных со злокачественными новообразованиями поджелудочной железы монотерапию инсулином применяли $12(23,08 \%)$ лиц, из них у 8 (66,67 \%) продолжительность диабета составляла менее 5 лет. Среди больных с колоректальным раком 5 лиц получали монотера- 
пию инсулином (8,33 \%), лишь 1 (20,00\%) пациент имел стаж диабета менее 5 лет. Выявлено вероятное влияние инсулинотерапии на возникновение рака поджелудочной железы (отношение шансов - 3,21; 95 \% доверительный интервал - 1,74-5,93; p < 0,001) и колоректального рака (отношение шансов - 3,13; 95 \% доверительный интервал - 1,85-5,28; p < 0,001).

Выводы. Полученные данные свидетельствуют о вероятной связи инсулинотерапии с возникновени- ем рака поджелудочной железы и колоректальной локализации у пациентов с сахарным диабетом 2 типа. Больные с раком поджелудочной железы требуют дополнительного обследования и исключения возможного T3cDM при впервые выявленном сахарном диабете.

Ключевые слова: сахарный диабет 2 типа, инсулинотерапия, рак поджелудочной железы и колоректальный рак.

Дата надходження до редакції 23.06.2020 p. 